\title{
"Analysis of key university leadership factors based on their international rankings (QS World University Rankings and Times Higher Education)"
}

\begin{tabular}{|c|c|}
\hline AUTHORS & $\begin{array}{l}\text { Maxim Polyakov (D https://orcid.org/0000-0001-7896-2486 } \\
\mathbb{R} \text { http://www.researcherid.com/rid/V-9971-2018 } \\
\text { Vladimir Bilozubenko (D https://orcid.org/0000-0003-1269-7207 } \\
\mathbb{R} \text { http://www.researcherid.com/rid/V-9965-2018 } \\
\text { Maxim Korneyev (D https://orcid.org/0000-0002-4005-5335 } \\
\mathbb{R} \text { http://www.researcherid.com/rid/B-7032-2018 } \\
\text { Natalia Nebaba (D https://orcid.org/0000-0003-1264-106X } \\
\mathbb{R} \text { http://www.researcherid.com/rid/U-8721-2017 }\end{array}$ \\
\hline ARTICLE INFO & $\begin{array}{l}\text { Maxim Polyakov, Vladimir Bilozubenko, Maxim Korneyev and Natalia Nebaba } \\
(2020) \text {. Analysis of key university leadership factors based on their international } \\
\text { rankings (QS World University Rankings and Times Higher Education). } \\
\text { Problems and Perspectives in Management, 18(4), 142-152. } \\
\text { doi:10.21511/ppm.18(4).2020.13 }\end{array}$ \\
\hline DOI & http://dx.doi.org/10.21511/ppm.18(4).2020.13 \\
\hline RELEASED ON & Tuesday, 24 November 2020 \\
\hline RECEIVED ON & Friday, 28 August 2020 \\
\hline ACCEPTED ON & Tuesday, 10 November 2020 \\
\hline LICENSE & $\begin{array}{l}(c) E Y \\
\text { This work is licensed under a Creative Commons Attribution } 4.0 \text { International } \\
\text { License }\end{array}$ \\
\hline JOURNAL & "Problems and Perspectives in Management" \\
\hline ISSN PRINT & $1727-7051$ \\
\hline ISSN ONLINE & $1810-5467$ \\
\hline PUBLISHER & LLC "Consulting Publishing Company "Business Perspectives" \\
\hline FOUNDER & LLC "Consulting Publishing Company "Business Perspectives" \\
\hline
\end{tabular}

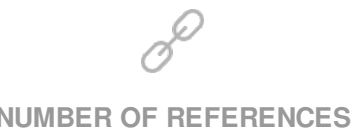

31

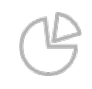

NUMBER OF FIGURES

0



NUMBER OF TABLES

5

(C) The author(s) 2021. This publication is an open access article. 


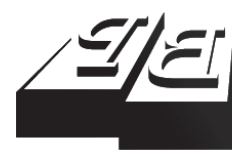

\section{BUSINESS PERSPECTIVES}

LLC "CPC "Business Perspectives" Hryhorii Skovoroda lane, 10, Sumy, 40022, Ukraine www.businessperspectives.org
Received on: $28^{\text {th }}$ of August, 2020 Accepted on: $10^{\text {th }}$ of November, 2020 Published on: $24^{\text {th }}$ of November, 202

(C) Maxim Polyakov, Vladimir Bilozubenko, Maxim Korneyev, Natalia Nebaba, 2020

Maxim Polyakov, Doctor of Economics, Associate Professor, Managing Partner at Noosphere Ventures Inc., Menlo Park, USA.

Vladimir Bilozubenko, Doctor of Economics, Associate Professor, Department of International Economic Relations, Regional Studies and Tourism, University of Customs and Finance, Dnipro, Ukraine.

Maxim Korneyev, Doctor of Economics, Professor, University of Customs and Finance, Department of International Economic Relations, Regional Studies and Tourism, Dnipro, Ukraine. (Corresponding author)

Natalia Nebaba, Ph.D. in Economics, Associate Professor, Department of International Economic Relations, Regional Studies and Tourism, University of Customs and Finance, Dnipro, Ukraine.
Maxim Polyakov (USA), Vladimir Bilozubenko (Ukraine), Maxim Korneyev (Ukraine), Natalia Nebaba (Ukraine)

\section{ANALYSIS OF KEY UNIVERSITY LEADERSHIP FACTORS BASED ON THEIR INTERNATIONAL RANKINGS (QS WORLD UNIVERSITY RANKINGS AND TIMES HIGHER EDUCATION)}

\begin{abstract}
In the context of globalization of the educational services market, competition between universities is becoming more intense. This manifests itself, among other things, in the struggle for positions in international university rankings. Given that universities are evaluated according to many criteria in such rankings, it becomes necessary to identify the most significant factors in determining their positions.

This study aims to identify the key factors determining the world's leading universities leadership in international university rankings. The numerical values of the criteria for compiling the QS World University Rankings (QS) and Times Higher Education (THE) rankings were an empirical basis for the study. The analysis covered the Top 50 universities (according to the QS ranking) and was conducted based on reports for 2020 and 2021.

At first, clustering was carried out (method - k-means); the data set was the combination of numerical values of QS and THE criteria (six and five criteria, respectively). The universities were divided into three clusters in 2020 (23, 19, 8 universities) and 2021 $(23,17,10$ universities). This showed the universities' leadership relative to each other for each year.

At the second stage, classification processing was performed (method - decision trees). As a result, criteria combinations that give an absolute separation of all clusters (2020five combinations; 2021 - eight combinations) were identified. The obtained combinations largely determine universities' affiliation to clusters; their criteria are recognized as key factors of their leadership in the rankings. This study's results can serve as guidelines for improving universities' positions in the rankings.
\end{abstract}

\section{Keywords globalization, universities, competition, international rankings, clustering, classification, leadership factors}

\section{JEL Classification $\quad$ C38, I23, M30}

\section{INTRODUCTION}

Global technological trends and the growing race for innovation, both between countries and between companies, are accompanied by increased demand for high-skilled professionals. This leads to an even greater increase in the importance of higher education and the expansion of universities' role in an innovative economy.

In the context of globalization of the educational services market, competition between universities is becoming more intense; this is taking place against the backdrop of general progress and increasing complexity of higher education systems. In this regard, achieving (maintaining) leadership and ensuring competitiveness are a priority 
for universities; this is increasingly reaching the world level and is a decisive factor in their sustainability. These issues determine the need for an appropriate comparative analysis to identify leaders, the degree and parameters of differences between universities, assessing competitive positions and advantages, etc., covering all areas and aspects of educational institutions' activities.

The need for benchmarking has prompted the need for leadership monitoring and evaluation tools. International university rankings have become such tools, perhaps the most important today. Their importance has grown significantly in the context of the globalization of higher education. Such rankings show the world's leading universities' potential and performance, reflecting their competitiveness, advantages, and authority at the global level. Struggle for positions in international rankings has become one of the manifestations of university competition, and increasing positions in such rankings are one of the forms of leadership in the global educational services market.

International university rankings are an objectively useful, versatile, and practically indispensable tool for a comprehensive and systematic comparison of universities, which, despite some skepticism, is widely used in management and marketing. However, it should be borne in mind that rankings assess universities according to many criteria, and therefore it becomes necessary to identify the most significant criteria in determining the positions of universities. Such criteria can be considered key factors in university leadership, which can be identified based on the analysis of the numerical values of the criteria for calculating university rankings. This will serve as an additional argument in justifying management decisions, as a guideline for marketing and increasing universities' competitiveness, especially strategies for improving the positions in international rankings.

\section{LITERATURE REVIEW}

The relevance of ensuring leadership and competitiveness is primarily due to the increasing importance of higher education in terms of socio-economic performance and development (Volchik et al., 2018). It has a decisive influence on regions and countries' economic and innovative potential, reducing social inequality and achieving sustainable development, making this area a priority object of state policy (Tvaronavičienè et al., 2018).

Rapid technological change is constantly increasing the importance of human capital, which re-actualizes and strengthens universities' role (Huang, 2018). They not only remain the traditional structure of knowledge, the center of their production for society, and the main mechanism for the transfer of experience and the formation of human capital but also serve as a basis for shaping ecosystems for innovation, performing a wide range of functions in national and regional innovation systems (Gosain, 2019; Krishna, 2017; Huang \& Chen, 2017; Singh et al., 2015). Universities have become an important business partner, enabling technology creation and transfer to the economy (García-Vega \& VicenteChirivella, 2020; Datta et al., 2019).
Universities play an important role as agents of cultural change, which is essential for sustainable development. New cultural elements can be incorporated into any university activity, especially teaching, innovation development, and scientific communication, to successfully influence society. As part of this role, it is advisable to strengthen universities' capacity, encompassing the processes of initiating, promoting, and modeling changes focused on sustainable development (Sułkowski et al., 2020).

The global trend of recent decades has been not only the increasing influence of universities on economic growth, but also the increase in their number, which has been observed in different countries and, of course, due to the growing need to generate new knowledge, innovate, and build human capital (Valero \& Van Reenen, 2019). An assessment of the direct and indirect positive effects of this, which manifested itself in the economy, showed the need to consider the revival of universities as one of the main mechanisms for ensuring economic growth (Mendy \& Widodo, 2018). From the perspective of countries and regions, this has drawn attention to ensuring leadership and competitiveness of universities in an increasingly open 
and competitive global educational services market. The globalization of higher education has led to the attraction of many universities from different countries to the world market. This has led to a significant intensification of competition, also fueled by the growing demand for highly qualified professionals (Deiaco et al., 2012).

Universities seek to maximize their status as producers and suppliers of a global positional product, such as educational services, which is reflected in a wide range of indicators that assess these institutions' capacity and performance (Musselin, 2018).

In the competition in the global educational services market, the tone is set, first of all, by the world's leading universities, which are at the forefront of the development of higher education and create benchmarks for other universities in all countries (Rust \& Kim, 2012). Therefore, studying the parameters of the world's leading universities' functioning in terms of identifying their advantages in the world market is of great interest (Ishchenko-Padukova et al., 2017). This can be used to shape state and regional policies in the development of higher education and various universities for strategic management, marketing, and competitiveness.

The problem of comparing universities arises not only in terms of competition but also in terms of their consolidation and merger, management of these processes from planning to full integration (Sułkowski et al., 2019). Comparison is also necessary for the formation of knowledge and technology transfer networking platforms (Novikova et al., 2020) and can be valuable in developing targeted forms of cooperation between universities and businesses (Rayevnyeva et al., 2018).

Scientometric (bibliometric) analysis is one of the most common methods for assessing and comparing universities' scientific productivity, but it only gives a narrow picture of their activities and is often insufficient (Cancino et al., 2017). Also, special indicators (for example, output-to-input indicators) of research performance (Abramo et al., 2020) are used to compare universities at the national and international levels, but they meet only particular objectives. To manage universities and increase their competitiveness, more complex comparisons are needed. This drew much attention to the international university rankings as a tool for monitoring and evaluating competitive positions. Such rankings are becoming increasingly inclusive in terms of the number of countries and universities represented and the assessment of various aspects of their activities. Therefore, international rankings are often seen as a reflection of universities' competitiveness in the global market. This makes the rankings a high-quality information product for analytics, which has a wide range of consumers, and an integral part of the global market's information field for educational services (Millot, 2015).

Different international university rankings have their similarities and differences, making it possible to compare them, including the use of data mining methods (İskender \& Bat1, 2015). Longitudinal patterns can also be studied for systematically calculated rankings. Comparing existing rankings shows their significant differences, especially given the different list of indicators and their significance. This is difficult to unify since it applies to different approaches to assessing productivity in science and education (Buela-Casal et al., 2007). Meanwhile, despite using authentic methodologies, there are reasonable similarities between the rankings' results (Aguillo et al., 2010). Given this, different rankings that have the same goals are almost complementary. Thus, the numerical values of the criteria, based on which the estimates of different ratings are calculated, can be combined and used in general for a comparative analysis, which will improve the quality of research.

The history of the use and development of universities' international rankings shows their importance in assessing the level of university competitiveness on the global educational services market, determining the degree of compliance of certain institutions with the indicators achieved by leading universities (Rust \& Kim, 2015). Therefore, rankings are considered one of the foundations of building a development strategy that covers the issues of increasing the competitiveness level. In the management and marketing of universities, there is a practical need to compare the rankings and the numerical values of various criteria based on which they are compiled. However, at the 
same time, there is an objective complexity due to many criteria of different nature and different scales of their numerical values, so their complex comparison is quite difficult. Besides, there is the task of determining the criteria that are actually more important in determining universities' positions in the rankings, as this allows setting priorities in management and marketing. The choice of the most important criteria is necessary, first of all, for the universities themselves, as this indicates the ways to increase their positions inings and achieve leadership in the educational services market. Assessing the significance of the criteria, based on which international rankings are calculated, is important for ensuring leadership and competitiveness, promoting universities in the global market, as well as, in general, for shaping university development strategies in the global environment (Štimac \& Šimić, 2012; Voropai et al., 2019). Practical areas of analysis of key university leadership factors based on international rankings are the study of the marketing environment of universities, a set of changes in opportunities and risks, as well as assessing the effectiveness of marketing tools in the university management systems (Petrunia et al., 2019).

\section{AIMS}

This study aims to highlight the key factors that determine the leadership of the world's leading universities in international university rankings, which allows ensuring the competitiveness in the global educational services market. The empirical basis for finding the key university leadership factors was a combination of numerical values of the criteria for compiling the main international rankings QS World University Rankings (QS) and Times Higher Education (THE). The analysis covered the Top 50 universities taken according to the QS ranking and, for comparison, was conducted based on 2020-2021 data. Combining the QS and THE criteria will improve benchmarks' quality to identify key factors in university leadership.

\section{METHODS}

International rankings' activities are evaluated according to a very large set of criteria (indica- tors), each of which is important for the final rank. When compiling the ranking, each criterion is measured by a numerical value, which is a quantitative parameter that characterizes a certain aspect of a university's capacity or performance. Therefore, the whole set of criteria for international ranking is a set of empirical data to assess a university's position as a whole. On the other hand, individual criteria can be seen as indicators of potential, performance, development level, and competitive advantages of the university. Based on this, the most significant criteria in determining universities' positions in the rankings are the key factors of their leadership. Focusing resources on building up such factors is more effective and in line with management and marketing objectives.

It is proposed to highlight key leadership factors from the list of criteria (combining the criteria for calculating QS and THE) based on two data mining tasks, namely clustering and classification. They allow searching for hidden, deep, and non-trivial patterns in large volumes of heterogeneous data. The application of clustering and classification is based on hypotheses that are common to various fields. This is primarily the compactness hypothesis, namely the assumption that similar objects more often lie in the same cluster than in the different ones, so compactly localized subsets are formed in the object space. The compactness hypothesis concerning the task formulated gives rise to working hypotheses about the positive relationship between the criteria of international rankings, the productive contribution of individual criteria to assessing universities' potential and performance, and significant similarities between leading universities according to the relevant criteria.

\section{Clustering of the Top 50 universities according to a set of numerical values of the international university rankings' criteria. Clustering is one of the tasks of data mining; it applies to "unsuper- vised learning". Its purpose is to see the objective structure in the absence of the initial division of objects into classes and identify the basic pattern, namely, dividing objects into clusters.}

Clustering involves dividing a set of similar objects into objectively existing homogeneous groups (clusters) according to their parameters' 
similarity in the multidimensional description of these objects. In this regard, clustering reflects the positioning of objects relative to each other, and the assignment of an object to one or another cluster is the characteristic of its positions in the total population.

An "object-property" table (OPT) is compiled for clustering. This is a table whose rows represent objects, i.e., universities, and the columns represent their properties introduced by the criteria for calculating the QS and THE rankings, which have numerical values ( $x$ parameter). The parameter $x$ means a discrete description of a certain property of the studied object $X$ (university), which allows structuring a set of such objects. Each object $X$ is described using a set of parameter values $x_{1}, \mathrm{x}_{2} \ldots$, $\mathrm{x}_{n}$. Thus, OPT summarizes a multidimensional clustering dataset that characterizes universities, which is the basis for clustering (Table 1).

Table 1. List of criteria for calculating $Q S$ and THE, whose numerical values are combined in an OPT

\begin{tabular}{ll:cl}
\hline \multicolumn{2}{c}{ QS criteria } & \multicolumn{2}{c}{ THE criteria } \\
\hline 1. & Citations per faculty. & 7. & Teaching. \\
2. & International students. & 8. & Research. \\
3. & International faculty. & 9. & Citations. \\
4. & Faculty student. & 10. & Industry income. \\
5. & Employer reputation. & 11. & International outlook. \\
6. & Academic reputation. & & \\
\hline
\end{tabular}

Following the empirical principle, OPT satisfies three conditions - consistency, completeness, and sufficiency - in describing the objects' properties. Specificity and horizontal equality of all criteria are accepted. The mutual influence between the criteria of each rating and the similarity between the parameters of the criteria of both rankings, are not taken into account.

Based on the list of QS and THE criteria and their numerical values, OPT was obtained as a multidimensional empirical data set. Based on the specifics of the data, the k-means algorithm was chosen for clustering, which is effective when the data form compact clusters that differ well from each other. The data are normalized. The distance between objects is the criterion for their similarity. Euclidean distance was chosen as a metric (Everitt et al., 2011).

To get correct results, one needs to check the quality of the data and determine the optimal number of clusters. This is done, firstly, based on three-dimensional visualization, which is built using the principal component analysis and multidimensional scaling, and, secondly, based on specially calculated indicators (the sum of squared error index, the trace index, the Dunn index, the Davies and Bouldin index, Calinski-Harabasz index, and PBM index). To calculate the optimal number of clusters and directly clustering, this study used the software implementation of the relevant mathematical tools shown on the ScienceHunter portal (http://sciencehunter.net).

Determining the key university leadership factors based on the classification analysis by numerical values of the criteria for calculating international university rankings. By dividing a set of objects into clusters, one can find relatively accurate differences between them by setting the most significant parameters for their division. The search for separation parameters is the task of classification analysis (classification in data mining can also be understood as the distribution of the studied objects by types, including for the recognition and assignment of any new objects to certain classes). Mathematical classification data processing is the basis for division. The result is a pattern that allows one to conclude a particular group of objects' characteristics, their differences from another group or groups. In this case, the previously obtained clusters are treated as classes, and the OPT with the numerical values of the criteria and the selected classes is converted into the training sample (TS) required for classification. The classification is subject to the specific research or management objectives, which determine its focus, use cases, and even methods chosen. In this paper, the classification aims to find the parameters that distinguish the clusters of universities with the greatest significance and determine the positions of each of them in the aggregate. These parameters are decisive in the positioning of universities in rankings and are recognized as key leadership factors. The classification result is expected to be used in management and marketing since processing allows choosing the most important one from a fairly large set of indicators to improve positions in the rankings. A targeted increase in these priority indicators, the number of which is much less than the whole list, will be more effective. 
For classification processing, this study will use logical-combinatorial methods, namely, the "decision trees" method, which is theoretically sound and practically confirmed its effectiveness (Vasylenko \& Shevchenko, 1979). The multiplace OPT dataset grouped by clusters (classes) is transformed into a training sample (TS), enabling us to assess the informativeness of both individual parameters and their arbitrary groups and identify those that indicate significant differences between the found clusters.

TS is a table of empirical data, consisting of many discrete sets of $X$, for each of which belonging to one or another class is known. The contribution of individual criteria is proposed to be evaluated using a formula that allows selecting the parameters with the greatest discriminating significance:

$$
V\left(x_{i 1}, \ldots x_{i j}\right)=\frac{1}{k} \sum_{\Delta \in \Gamma} \max \left(\frac{m_{\Delta y}}{m_{y}}\right),
$$

where $k$ is the number of classes (clusters), $m_{y}$ is the number of objects belonging to class (cluster) $Y, \Delta=t_{i 1}, t_{i 2}, \ldots t_{i j}\left(0 \leq t_{i j} \leq k_{i j}-1\right), j=1, \ldots, \Gamma$ means the arbitrary set of parameter values $x_{i 1}, \ldots, x_{i j}(1 \leq \Gamma \leq$ $n), m_{\Delta Y}$ denotes the number of sampling sets of the $m$ class, for which the relation $t_{i j}=x_{i j}(j=1, \ldots, \Gamma)$ is performed, $t_{i j}$ are the values of parameters $x_{i j}$ in the set of $\Delta, \Gamma$ means the variety of all sets of parameter values $x_{i 1}, \ldots, x_{i j}$.

This estimate (formula (1)) is calculated directly from the TS data, allows assessing the distinctive capacity of the entire TS and identifying relatively small combinations of criteria that have the maximum (preferably absolute) discriminating ability. These combinations include the main factors that most determine universities' positions in the general population. When the classes can be completely distinguished, this estimate takes a threshold of 1 .

Given the problem of improving the effectiveness of management and marketing, it is also necessary to assess the significance of each criterion included in combination with the most discriminating ability. Significance is considered the contribution of each parameter to the overall component of the information content of the obtained criteria combinations, that is, their discriminating ability, which affects universities' positions. To assess the significance of each criterion in combinations, the following function is proposed:

$W\left(x_{i j}\right)=1-V\left(x_{i 1}, \ldots x_{i j-1}, x_{i j+1}, \ldots x_{i s}\right), 1 \leq s \leq n$,

Since $V\left(x_{i 1}, \ldots, x_{i j-1}, x_{i j+1}, \ldots, x_{i s}\right) \leq 1, W\left(x_{i j}\right)$ will always be a positive value less than 1 .

The procedure for finding combinations of criteria with the maximum discriminating ability and assessing the significance of the parameters included in them will be performed using the software implementation of appropriate methods on the ScienceHunter portal (http://sciencehunter.net).

\section{RESULTS}

\section{The results of clustering the Top 50 universities by numerical values of the criteria for calculating} QS and THE. Summarizing the numerical values of the QS and THE criteria (Table 1) for 2020 for the Top 50 universities, this set was divided into three clusters, which allowed distinguishing leadership levels from I to III (Table 2).

Multidimensional comparison based on the criteria of two ratings simultaneously - QS and THE - has somewhat changed universities' positioning. Cluster I includes 23 universities from the general list. At the same time, it included universities with serial numbers in the OPT: $24,28,30,31,36$, and 39. Cluster II (19 universities) included universities numbered 11, 19,20, and universities numbered 44 to 50 . Thus, the joint use of the criteria of the two rankings adjusted the QS ranking, which is more objective.

In the QS 2021 ranking, the composition of the Top 50 universities has changed. Carnegie Mellon University, University of California, San Diego, Delft University of Technology, and University of Bristol were not included. Instead, the Top 50 included University of British Columbia, Shanghai Jiao Tong University, City University of Hong Kong, and Technical University of Munich. The set of parameters for clustering and the calculation methodology remained the same. Table 3 shows the clustering results for 2021. 
Table 2. Clustering results of the Top 50 universities by numerical values of the QS and THE calculation criteria, 2020

\begin{tabular}{|c|c|c|}
\hline $\begin{array}{c}\text { Cluster I } \\
\text { (23 universities) }\end{array}$ & $\begin{array}{c}\text { Cluster II } \\
\text { (19 universities) }\end{array}$ & $\begin{array}{c}\text { Cluster III } \\
\text { (8 universities) }\end{array}$ \\
\hline $\begin{array}{l}\text { 1. Massachusetts Institute of Technology (1). } \\
\text { 2. Stanford University (2). } \\
\text { 3. Harvard University (3). } \\
\text { 4. University of Oxford (4). } \\
\text { 5. California Institute of Technology (5). } \\
\text { 6. Swiss Federal Institute of Technology (6). } \\
\text { 7. University of Cambridge (7). } \\
\text { 8. University College London (8). } \\
\text { 9. Imperial College London (9). } \\
\text { 10. University of Chicago (10). } \\
\text { 11. National University of Singapore (12). } \\
\text { 12. Princeton University (13). } \\
\text { 13. Cornell University (14). } \\
\text { 14. University of Pennsylvania (15). } \\
\text { 15. Yale University (17). } \\
\text { 16. Columbia University (18). } \\
\text { 17. University of Michigan-Ann Arbor (21). } \\
\text { 18. Johns Hopkins University (24). } \\
\text { 19. University of California, Berkeley (28). } \\
\text { 20. University of Toronto (30). } \\
\text { 21. Northwestern University (31). } \\
\text { 22. University of California, Los Angeles (36). } \\
\text { 23. New York University (39). }\end{array}$ & $\begin{array}{l}\text { 1. Nanyang Technological University, } \\
\text { 2. Singapore (11). } \\
\text { 3. } \text { LPFL (École polytechnique fédérale de } \\
\text { 4. The University of Edinburgh (20). } \\
\text { 5. The University of Manchester (27). } \\
\text { 6. The Australian National University (29). } \\
\text { 7. The Hong Kong University of Science and } \\
\text { 8. King's College London (33). } \\
\text { 9. McGill University (35). } \\
\text { 10. The University of Melbourne (38). } \\
\text { 11. The University of Sydney (42). } \\
\text { 12. The University of New South Wales (43). } \\
\text { 13. The London School of Economics and } \\
\text { 14. University of California, San Diego (45). } \\
\text { 15. The Chinese University of Hong Kong (46). } \\
\text { 16. The University of Queensland (47). } \\
\text { 17. Carnegie Mellon University (48). } \\
\text { 18. University of Bristol (49). } \\
\text { 19. Delft University of Technology (50). }\end{array}$ & $\begin{array}{l}\text { 1. } \text { Tsinghua University (16). } \\
\text { 2. Peking University (22). } \\
\text { 3. } \text { The University of Tokyo (23). } \\
\text { 4. Duke University (25). } \\
\text { 5. Kyoto University (34). } \\
\text { 6. Seoul National University (37). } \\
\text { 7. Fudan University (40). } \\
\text { 8. } \\
\begin{array}{l}\text { Korea Advanced Institute of } \\
\text { Science \& Technology (41). }\end{array}\end{array}$ \\
\hline
\end{tabular}

Note: The serial number of the university in the OPT is given in parentheses.

Table 3. Clusterization results of the Top 50 universities by the numerical values of the criteria for calculating QS and THE, 2021

\begin{tabular}{|c|c|c|}
\hline $\begin{array}{c}\text { Cluster I } \\
\text { (23 universities) }\end{array}$ & $\begin{array}{c}\text { Cluster II } \\
\text { (17 universities) }\end{array}$ & $\begin{array}{c}\text { Cluster III } \\
\text { (10 universities) }\end{array}$ \\
\hline $\begin{array}{l}\text { 1. Massachusetts Institute of Technology (1). } \\
\text { 2. Stanford University (2). } \\
\text { 3. Harvard University (3). } \\
\text { 4. California Institute of Technology (4). } \\
\text { 5. University of Oxford (5). } \\
\text { 6. Swiss Federal Institute of Technology (6). } \\
\text { 7. University of Cambridge (7). } \\
\text { 8. Imperial College London (8). } \\
\text { 9. University of Chicago (9). } \\
\text { 10. University College London (10). } \\
\text { 11. National University of Singapore (11). } \\
\text { 12. Princeton University (12). } \\
\text { 13. University of Pennsylvania (16). } \\
\text { 14. Yale University (17). } \\
\text { 15. Cornell University (18). } \\
\text { 16. Columbia University (19). } \\
\text { 17. University of Michigan-Ann Arbor (21). } \\
\text { 18. Johns Hopkins University (25). } \\
\text { 19. University of Toronto (26). } \\
\text { 20. Northwestern University (29). } \\
\text { 21. University of California, Berkeley (30). } \\
\text { 22. New York University (35). } \\
\text { 23. University of California, Los Angeles (36). }\end{array}$ & $\begin{array}{l}\text { 1. Nanyang Technological University, } \\
\text { 2. Singapore (13). } \\
\text { EPFL (Écolepoly technique fédérale de } \\
\text { 3. The Unanne) (14). } \\
\text { 4. The University of Hong Kong (22). } \\
\text { 5. The Hong Kong University of Science and } \\
\text { Technology (27). } \\
\text { 6. The University of Manchester (28). } \\
\text { 7. The Australian National University (31). } \\
\text { 8. King's College London (32). } \\
\text { 9. McGill University (33). } \\
\text { 10. The University of Sydney (40). } \\
\text { 11. The University of Melbourne (41). } \\
\text { 12. The Chinese University of Hong Kong } \\
\text { (43). } \\
\text { 13. The University of New South Wales (44). } \\
\text { 14. University of British Columbia (45). } \\
\text { 15. The University of Queensland (46). } \\
\text { 16. City University of Hong Kong (48). } \\
\text { 17. The London School of Economics and } \\
\text { Political Science (49). }\end{array}$ & $\begin{array}{l}\text { 1. Tsinghua University (15). } \\
\text { 2. Peking University (23). } \\
\text { 3. The University of Tokyo (24). } \\
\text { 4. Fudan University (34). } \\
\text { 5. Seoul National University (37). } \\
\text { 6. Kyoto University (38). } \\
\text { 7. KAIST - Korea Advanced Institute } \\
\text { 8. Duke University (42). } \\
\text { 9. Shanghai Jiao Tong University (47). } \\
\text { 10. Technical University of Munich } \\
\text { (50). }\end{array}$ \\
\hline
\end{tabular}

Note: The serial number of the university in the OPT is given in parentheses. 
Table 4. Combinations of criteria with $100 \%$ discriminating ability, with each of them belonging to the rankings and an assessment of individual significance, 2020

\begin{tabular}{|c|c|c|c|c|c|c|c|}
\hline \multicolumn{2}{|c|}{ No. } & Property (rating) & Significance & Property (rating) & Significance & Property (rating) & Significance \\
\hline \multirow{5}{*}{  } & 1 & $\begin{array}{l}\text { International } \\
\text { students (QS) }\end{array}$ & 0.31 & $\begin{array}{l}\text { Teaching } \\
\text { (THE) }\end{array}$ & 0.26 & - & - \\
\hline & 2 & Teaching (THE) & 0.20 & Citations (THE) & 0.31 & - & - \\
\hline & 3 & $\begin{array}{l}\text { Citations per } \\
\text { faculty (QS) }\end{array}$ & 0.13 & $\begin{array}{l}\text { Teaching } \\
\text { (THE) }\end{array}$ & 0.28 & $\begin{array}{l}\text { Industry } \\
\text { income (THE) }\end{array}$ & 0.23 \\
\hline & 4 & $\begin{array}{l}\text { International } \\
\text { students (QS) }\end{array}$ & 0.22 & $\begin{array}{l}\text { Faculty } \\
\text { student (QS) }\end{array}$ & 0.09 & $\begin{array}{l}\text { Research } \\
\text { (THE) }\end{array}$ & 0.15 \\
\hline & 5 & $\begin{array}{l}\text { Teaching } \\
\text { (THE) }\end{array}$ & 0.17 & $\begin{array}{l}\text { Industry } \\
\text { income (THE) }\end{array}$ & 0.07 & $\begin{array}{l}\text { International } \\
\text { outlook (THE) }\end{array}$ & 0.13 \\
\hline
\end{tabular}

Determining the key university leadership factors based on the classification analysis by numerical values of the QS and THE calculation criteria. Clustering has established an objective division of universities into clusters, enabling us to find differences between them. The estimated quality (informativeness or discriminating ability) of TS according to the 2020 data was $100 \%$. The examination sample includes eight universities (seven correctly assigned to the class, and one incorrectly). Based on estimate (1), a combination of criteria with the maximum discriminating ability is determined. The assessment of TS quality and criteria informativeness showed that in this case, combinations with absolute (100\%) discriminating ability could be determined. Based on estimate (1), five combinations were obtained. Using formula (2), the significance of individual parameters of each combination was evaluated (Table 4).
Several combinations indicate the absence of a single classification rule. The obtained combinations of criteria are equivalent and can be used individually or in combination. According to 2020, in general, the following key factors are identified: "International students" (QS), "Teaching" (THE), "Citations" (THE), "Citations per faculty" (QS), "Faculty student" (QS), "Industry income" (THE), "Research" (THE), and "International outlook (THE).

Obviously, in different combinations, these factors have different significance. As Table 4 shows, the obtained combinations of criteria consist of indicators of both one and two rankings. Along with clarifying the positioning as a result of clustering, it is advisable to use the criteria of several rankings simultaneously (although the approach is applicable and useful for individual rankings as well).

Table 5. Combinations of criteria with $100 \%$ discriminating ability, with each of them belonging to the rankings and assessment of individual significance, 2021

\begin{tabular}{|c|c|c|c|c|c|c|c|}
\hline \multicolumn{2}{|c|}{ No. } & Property (rating) & Significance & Property (rating) & Significance & Property (rating) & Significance \\
\hline \multirow{8}{*}{ 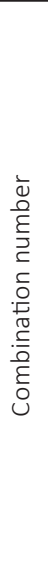 } & 1 & $\begin{array}{l}\text { Citations per faculty } \\
(\mathrm{QS})\end{array}$ & 0.03 & $\begin{array}{l}\text { International } \\
\text { students (QS) }\end{array}$ & 0.17 & $\begin{array}{l}\text { International faculty } \\
\text { (QS) }\end{array}$ & 0.22 \\
\hline & 2 & $\begin{array}{l}\text { Citations per faculty } \\
(\mathrm{QS})\end{array}$ & 0.12 & Citations (THE) & 0.14 & $\begin{array}{l}\text { International } \\
\text { outlook (THE) }\end{array}$ & 0.11 \\
\hline & 3 & $\begin{array}{l}\text { International } \\
\text { students (QS) }\end{array}$ & 0.08 & $\begin{array}{l}\text { International faculty } \\
\text { (QS) }\end{array}$ & 0.03 & Teaching (THE) & 0.2 \\
\hline & 4 & $\begin{array}{l}\text { International } \\
\text { students (QS) }\end{array}$ & 0.28 & $\begin{array}{l}\text { Employer } \\
\text { reputation (QS) }\end{array}$ & 0.03 & Teaching (THE) & 0.27 \\
\hline & 5 & $\begin{array}{l}\text { International } \\
\text { students (QS) }\end{array}$ & 0.26 & Teaching (THE) & 0.13 & Research (THE) & 0.03 \\
\hline & 6 & $\begin{array}{l}\text { International } \\
\text { students (QS) }\end{array}$ & 0.1 & Teaching (THE) & 0.14 & Citations (THE) & 0.03 \\
\hline & 7 & $\begin{array}{l}\text { International } \\
\text { students (QS) }\end{array}$ & 0.08 & Teaching (THE) & 0.21 & $\begin{array}{l}\text { International } \\
\text { outlook (THE) }\end{array}$ & 0.03 \\
\hline & 8 & $\begin{array}{l}\text { International } \\
\text { students (QS) }\end{array}$ & 0.14 & Research (THE) & 0.19 & $\begin{array}{l}\text { Industry } \\
\text { Income (THE) }\end{array}$ & 0.13 \\
\hline
\end{tabular}


The estimated quality of TS for 2021 accounted for $100 \%$. Examination sample - nine (nine correctly assigned to the class). Assessment of TS quality and the informativeness of the criteria showed that in this case, combinations with an absolute (100\%) discriminating ability could also be determined. Based on estimate (1), eight such combinations were obtained. Using formula (2), the significance of each combination's individual parameters was estimated (Table 5).

The following key factors of university leadership in 2021 are cumulatively identified: "Citations per faculty" (QS), "International students" (QS), "International faculty" (QS), "Citations" (THE), "International outlook" (THE), "Teaching" (THE), "Employer reputation" (QS), "Research" (THE), "Industry income" (THE). The resulting picture is slightly different from the results for 2020. First of all, there are more combinations, which indicates an increase in diversity. According to the frequency of inclusion in the combination of criteria with maximum discriminating ability, "International students" (QS) predominates, and "Teaching" (THE) is quite common. The chosen factors for both 2020 and 2021 are the main factors that determine university leadership. Repetition of factors ("International students", "Teaching", "Citations", "Citations per faculty", "Industry income", "Research" (THE), and "International outlook") in combinations of criteria both in 2020 and in 2021 once again speaks of their exceptional importance.

\section{DISCUSSION}

The presented technique is versatile and effective in the analysis of empirical data. The approach can be widely used in various areas of management and marketing, where there is a set of similar objects, a multi-criteria description of their properties (numerical values or other data types) and the need to divide objects into groups, and then identify the main factors dividing these groups. This provides extensive analytical and management capabilities. In marketing, clustering, complementing international rankings allows getting a better positioning of universities by combining the initial data of different rankings, which can be a basis for characterizing the competitive environment. Besides, the division into clusters demonstrates the overall structuring of universities worldwide as the "locomotive" of higher education and research, dividing these institutions into leadership levels. Also, clustering can cover any number of universities included in the rankings. Clustering is a benchmark for competitive evaluation, for the coordination and standardization of educational and R\&D programs, to create university alliances. The clustering results can be used to select universities in terms of grants, managing the mobility of scientists and graduates, cooperation, and the location of innovation infrastructure facilities at the universities. Each of the obtained clusters can be a separate object of analysis, including parametric analysis, studying the primary data or criteria for calculating ratings, highlighting similar characteristics in groups, average, maximum and minimum values, indicators of structure, and dynamics. This is necessary for the marketing of universities, both leaders and their followers, and universities not included in the rankings.

The selected key university leadership factors can be considered both in combination and separately as priority growth parameters to maximize or maintain competitive positions. An objective choice of key factors makes the proposed approach specific. In terms of management and marketing, the classification allows establishing the reasons and forming the architecture of leadership, which will guide new decisions and benchmarking. Assessing the significance of the indicators included in the desired combinations allows a deeper use of the university ranking data.

\section{CONCLUSION}

By combining the criteria for calculating QS and THE, and summarizing their numerical values into a single "object-property" table, clustering (method - k-means, metric - Euclidean distance) of the Top 50 universities (gradation composition in 2020 and 2021 is different) was carried out. Three clusters were identified in $2020(23,19$, and 8 universities) and 2021 (23, 17, and 10 universities). This reflects the uni- 
versities' leadership levels relative to each other. Based on the classification analysis (method - decision trees), combinations of criteria with the maximum discriminating ability (5 combinations in 2020 and 8 combinations in 2021), which give a 100\% separation of clusters, were identified. The significance of individual parameters included in each combination was also assessed. These parameters largely determine the positions of universities in the selected set of top 50. Therefore, they can be considered key leadership factors and priorities for building up to improve their position in the rankings. According to the data of 2020, the following key factors of university leadership were identified: "International students" (QS), "Teaching” (THE), "Citations" (THE), "Citations per faculty" (QS), "Faculty student" (QS), "Industry income" (THE), "Research" (THE), and "International outlook" (THE). For all combinations with maximum discriminating ability for 2021, the following factors were identified: "Citations per faculty" (QS), "International students" (QS), "International faculty” (QS), "Citations” (THE), "International outlook" (THE), "Teaching" (THE), "Employer reputation" (QS), "Research" (THE), and "Industry income" (THE). These results can be used to justify management and marketing decisions, evaluate the competitive environment, and develop measures to improve competitive positions. Prospective research is intended to establish the relationships between such leadership factors, which can be the basis for building cognitive maps to increase competitiveness.

\section{AUTHOR CONTRIBUTIONS}

Conceptualization: Maxim Polyakov, Vladimir Bilozubenko.

Data curation: Maxim Korneyev, Natalia Nebaba.

Formal analysis: Maxim Polyakov, Vladimir Bilozubenko, Maxim Korneyev, Natalia Nebaba.

Investigation: Maxim Polyakov, Vladimir Bilozubenko, Maxim Korneyev, Natalia Nebaba.

Methodology: Maxim Polyakov, Vladimir Bilozubenko.

Project administration: Maxim Polyakov.

Resources: Vladimir Bilozubenko, Maxim Korneyev, Natalia Nebaba.

Software: Maxim Polyakov, Vladimir Bilozubenko.

Supervision: Maxim Polyakov.

Validation: Maxim Korneyev, Natalia Nebaba.

Writing - original draft: Maxim Polyakov, Vladimir Bilozubenko, Maxim Korneyev,

Writing - review \& editing: Maxim Korneyev, Natalia Nebaba.

\section{REFERENCES}

1. Abramo, G., Aksens, D. W., \& D’Angelo, C. A. (2020). Comparison of research performance of Italian and Norwegian professors and universities. Journal of Informetrics, 14(2), 101023. https://doi. org/10.1016/j.joi.2020.101023

2. Aguillo, I. F., Bar-Ilan, J., Levene, M., \& Ortega, J. L. (2010). Comparing university rankings. Scientometrics, 85(1), 243-256. https://doi.org/10.1007/s11192010-0190-Z

3. Buela-Casal, G., Gutiérrez-Martínez, O., Bermúdez-Sánchez, M. P., \& Vadillo-Muñoz, O. (2007). Comparative study of international academic rankings of universities. Scientometrics, 71, 349-365. https://doi.org/10.1007/s11192007-1653-8

4. Cancino, C. A., Merigó, J. M., \& Coronado, F. C. (2017). A bibliometric analysis of leading universities in innovation research. Journal of Innovation \& Knowledge, 2(3), 106-124. https://doi. org/10.1016/j.jik.2017.03.006

5. Datta, S., Saad, M., \& Sarpong, D. (2019). National systems of innovation, innovation niches, and diversity in university systems. Technological Forecasting and Social Change, 143(C), 27-36. https://doi.org/10.1016/j.techfore.2019.02.005

6. Deiaco, E., Hughes, A., \& Mckelvey, M. (2012). Universities as strategic actors in the knowledge economy. Cambridge Journal of Economics, 36(3), 525-541. https://doi. org/10.1093/cje/bes024

7. Everitt, B., Landau, S., Leese, M., \& Stahl, D. (2011). Cluster Analysis. John Wiley \& Sons Ltd.

8. García-Vega, M., \& VicenteChirivella, Ó. (2020). Do university technology transfers increase firms' innovation? European Economic Review, 123. https://doi.org/10.1016/j. euroecorev.2020.103388

9. Gosain, A. (2019). Universities in the National Innovation Systems: Experiences from the AsiaPacific. Journal of Scientometric Research, 8(1), 62-67. https://doi. org/10.5530/jscires.8.1.9 
10. Huang, M.-H., \& Chen, D.Z. (2017). How can academic innovation performance in university-industry collaboration be improved? Technological Forecasting and Social Change, 123, 210-215. https://doi.org/10.1016/j. techfore.2016.03.024

11. Huang, S.-P. (2018). Effects of Innovative Education on Innovation Capability and Organizational Performance in High-Tech Industry. EURASIA Journal of Mathematics, Science and Technology Education, 14(3), 777-784. https:// doi.org/10.12973/ejmste/80127

12. Ishchenko-Padukova, O., Kazachanskaya, E., Movchan, I., \& Nawrot, L. (2017). Economy of education: National and global aspects. Journal of International Studies, 10(4), 246-258. https://doi. org/10.14254/2071-8330.2017/10$4 / 19$

13. İskender, E., \& Batı, G. B. (2015). Comparing Turkish Universities Entrepreneurship and Innovativeness Index's Rankings with Sentiment Analysis Results on Social Media. Procedia - Social and Behavioral Sciences, 195, 15431552. https://doi.org/10.1016/j. sbspro.2015.06.457

14. Krishna, V. (2017). Asia Pacific universities in national innovation systems: Experiences from the Asia-Pacific. In Universities in the National Innovation Systems. https://doi. org/10.4324/9781315111421-15

15. Mendy, D., \& Widodo, T. (2018). Do education levels matter on Indonesian economic growth? Economics \& Sociology, 11(3), 133-146. https://doi.org/10.14254/2071789X.2018/11-3/8

16. Millot, B. (2015). International rankings: Universities vs. higher education systems. International Journal of Educational Development, 40, 156-165. https://doi. org/10.1016/j.ijedudev.2014.10.004

17. Musselin, C. (2018). New forms of competition in higher education. Socio-Economic Review, 16(3), 657-683. https://doi.org/10.1093/ ser/mwy033

18. Novikova, I., Stepanova, A., Zhylinska, O., \& Bediukh, O. (2020). Knowledge and technol- ogy transfer networking platforms in modern research universities. Innovative Marketing, 16(1), 5765. http://dx.doi.org/10.21511/ im.16(1).2020.06

19. Petrunia, Y., Chentsov, V., Życzyński, N., \& Petrunia, V. (2019). Marketing environment and marketing management of universities in Ukraine: national and regional dominants. Innovative Marketing, 15(1), 1-12. http://dx.doi.org/10.21511/ im.15(1).2019.01

20. Rayevnyeva, O., Aksonova, I., \& Ostapenko, V. (2018). Formation interaction and adaptive use of purposive forms of cooperation of university and enterprise structures. Innovative Marketing, 14(3), 44-56. http://dx.doi.org/10.21511/ im.14(3).2018.05

21. Rust, V., \& Kim, S. (2012). The Global Competition in Higher Education. World Studies in Education, 13(1), 5-20. https://doi. org/10.7459/wse/13.1.02

22. Rust, V., \& Kim, S. (2015). Globalization and Global University Rankings. In Second International Handbook on Globalization, Education and Policy Research (pp. 167-180). Springer. https:// doi.org/10.1007/978-94-017-94930_11

23. Singh, A., Wong, P.-K., \& Ho, Y-P. (2015). The role of universities in the national innovation systems of China and the East Asian NIEs: An exploratory analysis of publications and patenting data. Asian Journal of Technology Innovation, 23(2), 140-156. https://doi.org/10. 1080/19761597.2015.1074515

24. Štimac, H., \& Šimić, M. L. (2012). Competitiveness in Higher Education: a Need for Marketing Orientation and Service Quality. Economics and Sociology, 5(2), 23-34. Retrieved from https:// www.economics-sociology.eu/ files/06_Stimac_Leko_1_1.pdf

25. Sułkowski, Ł., Dzimińska, M., \& Fijałkowska, J. (2020). A Conceptual Model Proposal: Universities as Culture Change Agents for Sustainable Development. Sustainability, 12(11), 1-23. https://doi org/10.3390/su12114635
26. Sułkowski, Ł., Fijałkowska, J., \& Dzimińska, M. (2019). Mergers in higher education institutions: a proposal of a novel conceptual model. Managerial Finance, 45(10/11), 1469-1487. https://doi. org/10.1108/MF-01-2018-0048

27. Tvaronavičienè, M., Tarkhanova, E., \& Durglishvili, N. (2018). Sustainable economic growth and innovative development of educational systems. Journal of International Studies, 11(1), 248-256. https://doi.org/10.14254/20718330.2018/11-1/19

28. Valero, A., \& Van Reenen, J. (2019). The economic impact of universities: Evidence from across the globe. Economics of Education Review, 68, 53-67. https://doi.org/10.1016/j. econedurev.2018.09.001

29. Vasylenko, Y. A., \& Shevchenko, H. Y. (1979). Analytical Method for Test Finding. Avtomatyka, 2, 3-8.

30. Volchik, V., Oganesyan, A., \& Olejarz, T. (2018). Higher education as a factor of socio-economic performance and development. Journal of International Studies, 11(4), 326-340. https://doi. org/10.14254/2071-8330.2018/11$4 / 23$

31. Voropai, O., Pichyk, K., \& Chala, N. (2019). Increasing competitiveness of higher education in Ukraine through value co-creation strategy. Economics and Sociology, 12(4), 228-240. https://doi.org/10.14254/2071789X.2019/12-4/14 